ORIGINAL ARTICLE

\title{
Evaluation of the process conditions for the production of microbial carotenoids by the recently isolated Rhodotorula mucilaginosa URM 7409
}

\author{
Avaliação das condições de processo para a produção de \\ carotenoides microbianos pela recém-isolada Rhodotorula \\ mucilaginosa URM 7409
}

\author{
Whallans Raphael Couto Machado ${ }^{1 *}$ (1), Lucas Gomes da Silva', \\ Ellen Silva Lago Vanzela ${ }^{1}$, Vanildo Luiz Del Bianchi ${ }^{1}$ \\ ${ }^{1}$ Universidade Estadual Paulista (UNESP), Instituto de Biociências, Letras e Ciências Exatas (IBILCE), São José do \\ Rio Preto/SP - Brasil
}

${ }^{*}$ Corresponding Author: Whallans Raphael Couto Machado, Universidade Estadual Paulista (UNESP), Instituto de Biociências, Letras e Ciências Exatas (IBILCE), Rua Cristóvão Colombo, 2265, CEP: 15054-000, São José do Rio Preto/SP - Brasil, e-mail: whallansfm@hotmail.com

\begin{abstract}
This study aimed to improve the physical and nutritional process conditions for the production of carotenoids by the newly isolated Rhodotorula mucilaginosa, a red basidiomycete yeast. The carotenoid bioproduction was improved using an experimental design technique, changing the process characteristics of agitation (130 rpm to $230 \mathrm{rpm})$ and temperature $\left(25^{\circ} \mathrm{C}\right.$ to $\left.35^{\circ} \mathrm{C}\right)$ using seven experiments, followed by a $2^{5-1}$ fractional design to determine the relevant factors that constitute the culture medium (glucose, malt extract, yeast extract, peptone and initial pH). A complete second order experimental design was then carried out to optimize the composition of the culture medium, the variables being yeast extract $(0.5$ to $3.5 \mathrm{~g} / \mathrm{L})$, peptone ( 1 to $5 \mathrm{~g} / \mathrm{L})$ and the initial pH (5.5 to 7.5$)$, with 17 experiments. The maximum carotenoid production was $4164.45 \mu \mathrm{g} / \mathrm{L}(252.99 \mu \mathrm{g} / \mathrm{g})$, obtained in $144 \mathrm{~h}$ in $\mathrm{YM}$ (yeast malt) medium with $30 \mathrm{~g} / \mathrm{L}$ glucose, $10 \mathrm{~g} / \mathrm{L}$ malt extract, $2 \mathrm{~g} / \mathrm{L}$ yeast extract, $3 \mathrm{~g} / \mathrm{L}$ peptone, an initial $\mathrm{pH} 6$, $130 \mathrm{rpm}$ and $25^{\circ} \mathrm{C}$, demonstrating the potential of this yeast as a source of bio-pigments. In this work, the nitrogen sources were the factors that most influenced the intracellular accumulation of carotenoids. The yeast R. mucilaginosa presented high production at a bench level and may be promising for commercial production.
\end{abstract}

Keywords: Basidiomycota; Pigmented; Submerged culture; $\beta$-Carotene; Experimental design; Optimization; Rhodotorula.

\section{Resumo}

Este estudo teve como objetivo melhorar as condições físicas e nutricionais do processo de produção de carotenoides pela recém-isolada Rhodotorula mucilaginosa, uma levedura basidiomiceta vermelha. A melhoria da bioprodução de carotenoides foi obtida pela técnica de delineamento experimental, alterando as 
características dos processos [agitação (130 rpm a $230 \mathrm{rpm})$ e temperatura $\left(25^{\circ} \mathrm{C}\right.$ a $\left.35^{\circ} \mathrm{C}\right)$ ] com sete experimentos, e após um planejamento fracionário $2^{5-1}$ para a classificação dos fatores relevantes que constituem o meio de cultura (glicose, extrato de malte, extrato de levedura, peptona e pH inicial). Um delineamento experimental de segunda ordem completo foi realizado para otimizar a composição do meio de cultura e as variáveis foram: extrato de levedura $(0,5$ a 3,5 g/L), peptona (1 a $5 \mathrm{~g} / \mathrm{L})$ e pH inicial $(5,5$ a 7,5), com 17 experimentos. A produção máxima de carotenoide foi de $4.164,45 \mu \mathrm{g} / \mathrm{L}(252,99 \mu \mathrm{g} / \mathrm{g})$ em $144 \mathrm{~h}$, em meio YM com $30 \mathrm{~g} / \mathrm{L}$ de glicose, $10 \mathrm{~g} / \mathrm{L}$ de extrato de malte, $2 \mathrm{~g} / \mathrm{L}$ de extrato de levedura e $3 \mathrm{~g} / \mathrm{L}$ de peptona, e pH inicial $6,130 \mathrm{rpm}$ a $25^{\circ} \mathrm{C}$. Neste trabalho, as fontes de nitrogênio foram os fatores que mais influenciaram o acúmulo de carotenoides intracelular. A levedura $R$. mucilaginosa apresentou alta produção em nível de bancada, podendo ser promissora para a produção comercial.

Palavras-chave: Basidiomicota; Pigmento; Cultivo submerso; $\beta$-Caroteno; Delineamento experimental; Otimização; Rhodotorula.

\section{Introduction}

Biomolecules produced by the secondary metabolism of microorganisms are receiving much attention by researchers. Amongst these biomolecules, carotenoids stand out for exhibiting several important biological properties such as provitamin A, antioxidant and anticancer activities, besides conferring coloration to the industrialized foods (Gómez et al., 2014; Ünlü \& Takaç, 2011; Wang et al., 2014).

The industrial production of these microorganisms (bacteria, fungi, microalgae and yeast) has several advantages, such as a small area for cultivation, rapid cell growth, easy scale up and adaptation to various sugar and nitrogen sources (Venil et al., 2013). On the other hand, not all microorganisms have the desired production capacity. The use of prospecting techniques allows for the discovery of new microorganisms with this potential (Chang et al., 2016; Singh et al., 2014).

Of the different sources of carotenoids, yeasts of the genus Rhodotorula have been reported as carotenogenic yeasts or pink yeasts due to their production of carotenoids. They are unicellular, their morphology has been described as soft, smooth and moist, and sometimes the presence of mucoid provides a high growth rate. They do not compete with food production and produce a wide variety of secondary metabolites (saponifiable lipids for the production of biodiesel, antibactericides, organic acids, B vitamins and enzymes), that can be obtained simultaneously in the biorefinery. In addition, they are easily adaptable to different nutritional sources, making them yeasts of industrial interest (Mao et al., 2012; Venil et al., 2013; Yoo et al., 2016).

Currently, there is a great interest in carotenoids due to their use in dietary supplements, as food coloring and as additives for pharmaceuticals and cosmetics. The demand for carotenoids has increased by $3.9 \%$ per year on the global market (Saini et al., 2018), but much of this market is dominated by chemical synthesis. These synthetic molecules have an impact on human health (toxicity, hypersensitivity and carcinogenicity) (Amchova et al., 2015) which has a negative effect on processed foods. On the other hand, the use of microbial sources could improve this negative characteristic for consumers, in addition to enriching the product with antioxidants and antimicrobial agents and being able to label it as containing natural dyes, causing no health malfunctions (Yolmeh \& Khomeiri, 2017).

The production of bio-colorants, in relatively pure and concentrated forms, is the main technological challenge for this industry. The strategy to improve the process conditions and change the nutritional sources may positively reflect on the production of carotenoids by microorganisms (Machado \& Burkert, 2015), and the use of statistical tools to study these factors and improve the process is essential.

Statistical methodologies such as factorial designs and central composite rotational designs (CCRD) may provide a comprehension of the factors involved in bioproduction based on experimental trials. These tools make it possible to reduce the number of tests without losing the response, as well as making an evaluation 
in the range of the factors studied, selecting only the determinant and significant factors to be evaluated in another design, aiming at higher production (Dhaliwal \& Chandra, 2015). The non-significant elements in the study can be omitted in the new experiment and hence these statistical tools can be adopted as a strategy to increase the production of carotenoids (Machado \& Burkert, 2015; Valduga et al., 2007). Thus, the objective of this work was to carry out a screening of yeasts with the potential for carotenoid production using an experimental design technique, studying the effects of the process operating conditions (agitation and temperature), as well as the composition of the culture medium in order to isolate yeasts with the best potential for this application (Rhodotorula mucilaginosa).

\section{Material and methods}

\subsection{Screening and isolation of the yeasts}

Samples were collected from soil, leaves and flowers in a region of environmental biodiversity (latitude 20.785218 and longitude -49.359897 ) and stored in pre-sterilized high-density polyethylene thermoplastic containers until the analyses were carried out. Samples were randomly collected from soil, tree bark, flowers and grass in an area of environmental biodiversity near the research laboratory. The samples obtained were transferred to $250 \mathrm{~mL}$ conical flasks containing $50 \mathrm{~mL}$ of yeast and malt extract medium (YM: $3 \mathrm{~g} / \mathrm{L}$ yeast extract, $3 \mathrm{~g} / \mathrm{L}$ malt extract, $5 \mathrm{~g} / \mathrm{L}$ peptone and $10 \mathrm{~g} / \mathrm{L}$ glucose) and incubated at $25^{\circ} \mathrm{C}$ and $150 \mathrm{rpm}$ for $48 \mathrm{~h}$ for microbial enrichment. They were then inoculated in Petri dishes with YM agar medium and incubated at $25^{\circ} \mathrm{C}$ for $120 \mathrm{~h}$ (Cabral et al., 2011).

Yeast colonies that showed yellow to red coloring were transferred to test tubes with YM agar medium and incubated at $25{ }^{\circ} \mathrm{C}$ until satisfactory growth. Isolation of the yeasts was confirmed on YM agar Petri dishes at $25{ }^{\circ} \mathrm{C}$ for $120 \mathrm{~h}$ (Valduga et al., 2007) and the purity of the microorganism was checked by microscopic examination. Confirmation of the yeast was carried out in PCA $(23.5 \mathrm{~g} / \mathrm{L})$, a selective medium for yeasts, with $50 \mathrm{mg} / \mathrm{L}$ chloramphenicol (Neo Química ${ }^{\circledR}$ ) (Cabral et al., 2011; Pereira et al., 2014).

\subsection{Microorganism maintenance and reactivation}

The microorganisms were maintained in slant culture tubes with GYMP agar $(2 \mathrm{~g} / \mathrm{L}$ glucose, $1 \mathrm{~g} / \mathrm{L}$ malt extract, $0.5 \mathrm{~g} / \mathrm{L}$ yeast extract, $0.2 \mathrm{~g} / \mathrm{L} \mathrm{NaH} \mathrm{PO}_{4}$ and $1.8 \mathrm{~g} / \mathrm{L}$ agar) and mineral oil, under refrigeration at $4{ }^{\circ} \mathrm{C}$, and replicated every three months (Lopes et al., 2017). For reactivation, replication from stock cultures was carried out in test tubes with YM medium, incubating at $25^{\circ} \mathrm{C}$ for $48 \mathrm{~h}$.

\subsection{Inoculum}

One milliliter of sterile peptone water was added to the medium containing the activated microorganism (previous step), to obtain a cell suspension by scraping the surface of the medium. This was transferred to test tubes containing $9 \mathrm{~mL} \mathrm{YM}$ broth and maintained at $25{ }^{\circ} \mathrm{C}$ for $48 \mathrm{~h}$. The cultures were then stirred on a vortex and transferred to $250 \mathrm{~mL}$ conical flasks containing $50 \mathrm{~mL}$ YM broth, previously sterilized at $121^{\circ} \mathrm{C}$ for $15 \mathrm{~min}$. These cultures were incubated at $150 \mathrm{rpm}$ and $25^{\circ} \mathrm{C}$, either for $48 \mathrm{~h}$ or the time required for the cell count to reach $10^{7}$ cells $/ \mathrm{mL}$, counting in a Neubauer chamber (Cipolatti et al., 2015).

\subsection{Carotenoid bioproduction and yeast identification}

Carotenoid bioproduction was carried out in an orbital shaker (Tecnal, TE 424, Brazil) in $250 \mathrm{~mL}$ conical flasks containing $112.5 \mathrm{~mL}$ YM medium at an initial $\mathrm{pH}$ 6.0. A ten percent inoculum was added and the cultivation started with $1 \times 10^{7}$ cells $/ \mathrm{mL}$, incubating at $25^{\circ} \mathrm{C}$ and $180 \mathrm{rpm}$ for $144 \mathrm{~h}$ (Machado \& Burkert, 2015). 
Samples were collected at the end of cultivation to determine the biomass by a gravimetric method and also the $\mathrm{pH}$ value and total carotenoid concentration.

Based on the bioproduction results, the yeast strain with the highest yield was selected for DNA analysis (PCR). It was identified, stored and made available to all researchers by the Micoteca URM at the Federal University of Pernambuco, Brazil.

\subsection{Experimental design}

The design of the study consisted of three steps: (i) analysis of the operational conditions of the process; (ii) preliminary analysis of the factors influencing the behavior of Rhodotorula mucilaginosa in YM medium and; (iii) determination of the effects of these factors on carotenoid production for optimization and subsequent validation of the process operating conditions.

A central composite design (CCD) with four experiments and three replicates at the central point was used first. The independent variables (factors) were agitation $(130$ to $230 \mathrm{rpm})$ and temperature $\left(25^{\circ} \mathrm{C}\right.$ to $\left.35^{\circ} \mathrm{C}\right)$.

After the statistical analysis, a second factorial design was carried out $\left(2^{5-1}\right)$. To determine the effects of the five factors on carotenoid production, it was proposed to use the effect of the graph together with an alpha ( $\alpha$ ) of $5 \%$, using Statistica ${ }^{\circledR}$ software version 10.0. The factors investigated were the components of the YM medium (yeast extract (1 to $5 \mathrm{~g} / \mathrm{L}$ ), peptone (1 to $10 \mathrm{~g} / \mathrm{L}$ ), glucose (10 to $30 \mathrm{~g} / \mathrm{L}$ ), malt extract ( 1 to $10 \mathrm{~g} / \mathrm{L}$ ) and the initial $\mathrm{pH}$ (4 to 6)). The results found for each factor were considered for the next experiment in sequence.

After confirming the significance of the effects of the factors, the third stage was carried out, a central composite rotatable design (CCRD) with 14 experiments and three replicates at the central points, studying the significant variables of yeast extract $(0$ to $2 \mathrm{~g} / \mathrm{L})$, peptone $(0$ to $2 \mathrm{~g} / \mathrm{L})$ and glucose $(30$ to $50 \mathrm{~g} / \mathrm{L})$. The three variables were studied at three levels: low $(-1)$, medium $(0)$ and high $(+1)$. The CCRD was designed using Statistica ${ }^{\circledR}$ software version 10.0 and the other non-significant process variables were fixed as follows: malt extract $1 \mathrm{~g} / \mathrm{L}$, initial $\mathrm{pH} 6.0$, with agitation and temperature at the highest condition obtained, namely $130 \mathrm{rpm}$ and $25^{\circ} \mathrm{C}$. Table 1 shows the treatments carried out with the levels tested. The dependent variables or responses of the experimental design were the volumetric $(\mu \mathrm{g} / \mathrm{L})$ and specific $(\mu \mathrm{g} / \mathrm{g})$ concentrations of carotenoids and the biomass $(\mathrm{g} / \mathrm{L})$.

Table 1. Variables used in the growth of $R$. mucilaginosa to obtain carotenoids.

\begin{tabular}{cccccc}
\hline Variables & \multicolumn{5}{c}{ Levels } \\
\cline { 2 - 6 } & $\mathbf{- 1 . 6 8}$ & $-\mathbf{1}$ & $\mathbf{0}$ & $\mathbf{+ 1}$ & $\mathbf{+ 1 . 6 8}$ \\
\hline Yeast extract $(\mathbf{g} / \mathbf{L})$ & 0 & 0.4 & 1 & 1.60 & 2 \\
Peptone $(\mathbf{g} / \mathbf{L})$ & 0 & 0.4 & 1 & 1.60 & 2 \\
Glucose $(\mathbf{g} / \mathbf{L})$ & 30 & 34 & 40 & 46 & 50 \\
\hline
\end{tabular}

The results were evaluated by linear regression testing the complete quadratic model with interactions. The non-significant parameters were eliminated from the model by the Student $t$-test at $5 \%$ of significance, resulting in a polynomial empirical model for these three process variables (Equation 1):

$Y=\beta_{0}+\beta_{1} A+\beta_{2} B+\beta_{3} C+\beta_{11} A^{2}+\beta_{22} B^{2}+\beta_{33} C^{2}+\beta_{12} A B+\beta_{13} A C+\beta_{23} B C$

where $\mathrm{Y}$ is the response measured; $\beta_{0}$ is the model intercept; $\beta_{1}, \beta_{2}$ and $\beta_{3}$ are linear coefficients; $\beta_{11}, \beta_{22}$ and $\beta_{33}$ are the quadratic coefficients; $\beta_{12}, \beta_{13}$ and $\beta_{23}$ are interaction coefficients and $\mathrm{A}, \mathrm{B}$ and $\mathrm{C}$ are independent coded variables.

The quality of the models developed was evaluated by two types of value: coefficient of determination $\mathrm{R}^{2}$ (capacity to explain the variance) and $p$-value, obtained from ANOVA. The adjusted empirical polynomial equations were expressed in contour form and three-dimensional plots, to illustrate the relationship between 
the responses as a function of the combination of the two factors to be optimized, keeping the other variables in central positions. The interaction of any two variables of the study can be examined from the prototype of the contour plots. Furthermore, the optimized numerical method was used to obtain optimal regions (optimal solutions).

\subsection{Validation of the model}

To confirm the theoretical results obtained from the adjusted polynomial equations, the culture was carried out in triplicate under the conditions described as optimal, to confirm the legitimacy of the models generated by the software. The results obtained for the volumetric and specific concentrations of the carotenoids were compared with the values predicted by the mathematical model.

\subsection{Recovery of total carotenoids}

Total carotenoid recovery was carried out according to the methodology described by Michelon et al. (2012) and Cipolatti et al. (2015). The biomass was centrifuged at $3439 \times \mathrm{g}$ for $10 \mathrm{~min}$, transferred to a Petri dish, dried in a freeze-dryer for $48 \mathrm{~h}$, macerated in a mortar and standardized using a Tyler $\mathrm{n}^{\circ} 115$ sieve. After the standardization step, $0.05 \mathrm{~g}$ of biomass were submitted to lysis with $2 \mathrm{~mL}$ of rupture agent: dimethyl sulfoxide or DMSO $\left(\left(\mathrm{CH}_{3}\right)_{2} \mathrm{SO}\right)$ and then agitated by vortex for $1 \mathrm{~min}$ every 15 minutes for $1 \mathrm{~h}$. After rupture, $8 \mathrm{~mL}$ of acetone were added and the mixture centrifuged $(3439 \times \mathrm{g}$ for $10 \mathrm{~min})$. The supernatant was then separated from the precipitate and several successive extractions carried out to total cell whitening.

The supernatants were combined and $10 \mathrm{~mL}$ of $20 \% \mathrm{NaCl}(\mathrm{p} / \mathrm{v})$ and $10 \mathrm{~mL}$ of petroleum ether added in order to form two phases. The polar phase was collected and the excess of water removed using sodium sulphate $\left(\mathrm{Na}_{2} \mathrm{SO}_{4}\right)$, originating the extracts containing the carotenoids (Michelon et al., 2012).

\subsection{Determination of total carotenoids}

The total carotenoid concentration in the extracts was determined in a spectrophotometer at $448 \mathrm{~nm}$ (Cabral et al., 2011), expressed as its major carotenoid ( $\beta$-carotene in petroleum ether, whose specific absorptivity is $\mathrm{A}_{\mathrm{cm}}^{1 \%}=2592$ ), according to Equation 2 (David, 1976).

$$
\mathrm{TC}=\frac{\mathrm{A} * \mathrm{~V}^{*} 10^{6}}{\mathrm{~A}_{\mathrm{lcm}}^{1 \%} * 100 * \mathrm{~m}_{\text {sample }}}
$$

where TC is the total carotenoid concentration $(\mu \mathrm{g} / \mathrm{g}) ; A$ is the absorbance; $V$ is the volume $(\mathrm{mL}) ; \mathrm{m}_{\text {sample }}$ is the dry cell mass $(\mathrm{g})$ and $\mathrm{A}_{\mathrm{lcm}}^{1 \%}$ is the specific absorptivity. To calculate the volumetric concentration of total carotenoids $(\mu \mathrm{g} / \mathrm{L})$ using the result obtained for the concentration of total carotenoids $(\mu \mathrm{g} / \mathrm{g})$ and the biomass concentration $(\mathrm{g} / \mathrm{L})$, a unit conversion was carried out.

\subsection{Determination of biomass}

The cells were centrifuged $(3439 \times \mathrm{g})$ at $25^{\circ} \mathrm{C}$ for $10 \mathrm{~min}$ to separate the supernatant, washed with distilled water and centrifuged again. The cell mass was quantified after drying at $105^{\circ} \mathrm{C}$ (Fanem SE-320) to constant mass, according to Association of Official Analytical Chemists (2012). 


\section{Results and discussion}

Thirty colonies were isolated from the environmental samples, and eight presented orange and pink pigmentation, with emphasis on the genus Rhodotorula. This group of yeasts are abundant in various regions, such as Patagonia and near Cheon city in South Korea (Libkind \& Van Broock, 2006; Yoo et al., 2016). According to Chang et al. (2016), 64.5\% of all yeasts isolated from the Taiwanese sea coast contain Rhodotorula.

Table 2 shows the bioproduction in terms of biomass and carotenoid concentrations (specific and volumetric) for eight selected yeasts. The yeast with the highest bio-pigment yield $(635.94 \mu \mathrm{g} / \mathrm{L})$ and cell growth $(6.30 \mathrm{~g} / \mathrm{L})$ was UYG9. Identification (PCR) by the URM Fungal Collection verified that this yeast was Rhodotorula mucilaginosa, obtained from soil samples. This yeast was deposited in the same institution, identified with the access code of URM 7409.

The yeasts XPS2 and DRG3 showed high volumetric concentrations of carotenoids and no significant difference from UYG9, but the strain UYG9 presented higher values for volumetric and biomass concentrations.

Table 2. Bioproduction of carotenoids by the isolated yeasts.

\begin{tabular}{|c|c|c|c|}
\hline Strains & Biomass $(\mathrm{g} / \mathrm{L})$ & $\mathrm{SCC}(\mu \mathrm{g} / \mathrm{g})$ & $\mathrm{VCC}(\mu \mathrm{g} / \mathrm{L})$ \\
\hline XPS2 & $5.42 \pm 0.12 b$ & $107.90 \pm 7.14 \mathrm{ab}$ & $584.48 \pm 38.70 \mathrm{ab}$ \\
\hline DRG3 & $5.27 \pm 0.03 b c$ & $108.51 \pm 3.64 \mathrm{ab}$ & $571.51 \pm 19.16 a b$ \\
\hline EGE5 & $3.88 \pm 0.13 \mathrm{e}$ & $122.46 \pm 3.53 \mathrm{a}$ & $474.55 \pm 18.03 c$ \\
\hline RTH6 & $4.98 \pm 0.15 c$ & $56.84 \pm 4.10 \mathrm{~d}$ & $283.35 \pm 20.42 \mathrm{e}$ \\
\hline UHJ7 & $4.60 \pm 0.17 d$ & $111.69 \pm 3.35 \mathrm{ab}$ & $513.78 \pm 21.76 b c$ \\
\hline ODK8 & $6.18 \pm 0.08 \mathrm{a}$ & $88.29 \pm 7.27 c$ & $545.94 \pm 44.97 b c$ \\
\hline UYG9 & $6.30 \pm 0.03 a$ & $100.94 \pm 9.21 b c$ & $635.94 \pm 58.01 \mathrm{a}$ \\
\hline UG10 & $3.27 \pm 0.17 f$ & $104.03 \pm 3.21 b$ & $339.85 \pm 10.48 d$ \\
\hline
\end{tabular}

Mean \pm deviation. Lowercase letters in the same column mean the samples differ statistically from each other $(p<0.05)$. SCC $=$ Specific concentration of carotenoids. VCC $=$ Volumetric concentration of carotenoids.

After the yeast URM 7409 was selected, an experimental design (CCD) was carried out, evaluating the operational cultivation factors as presented in Table 3 . The results showed that lower agitation $(130 \mathrm{rpm})$ and temperature $\left(25^{\circ} \mathrm{C}\right)$ favoured the production of carotenoids by this microorganism $(91.78 \mu \mathrm{g} / \mathrm{g}$ and 679.15 $\mu \mathrm{g} / \mathrm{L}$, respectively). Thus, the operational conditions of agitation and temperature were standardized according to this plan and a new $2^{5-1}$ experimental design used to optimize the culture medium.

Table 3. $2^{2}$ Central composite design (real and coded values) to maximize the process conditions (agitation and temperature).

\begin{tabular}{|c|c|c|c|c|c|}
\hline Assay & $\mathbf{X}_{1}$ & $\mathrm{X}_{2}$ & $Y_{1}$ & $\mathrm{Y}_{2}$ & $Y_{3}$ \\
\hline 1 & $-1(130)$ & $-1(25)$ & 7.4 & 91.78 & 679.15 \\
\hline 2 & $+1(230)$ & $-1(25)$ & 6.55 & 66.69 & 436.83 \\
\hline 3 & $-1(130)$ & $+1(35)$ & 2.7 & 48.85 & 131.89 \\
\hline 4 & $+1(230)$ & $+1(35)$ & 3.65 & 17.49 & 63.85 \\
\hline 5 & $0(180)$ & $0(30)$ & 6.8 & 55.94 & 385.95 \\
\hline 6 & $0(180)$ & $0(30)$ & 6.8 & 54.52 & 376.29 \\
\hline 7 & $0(180)$ & $0(30)$ & 7.1 & 55.61 & 383.74 \\
\hline
\end{tabular}

$\mathrm{X}_{1}=$ Agitation $(\mathrm{rpm}) . \mathrm{X}_{2}=$ Temperature $\left({ }^{\circ} \mathrm{C}\right) . \mathrm{Y}_{1}=$ Biomass $(\mathrm{g} / \mathrm{L}) . \mathrm{Y}_{2}=$ Specific concentration of carotenoids $(\mu \mathrm{g} / \mathrm{g}) . \mathrm{Y}_{3}=\mathrm{Volumetric}$ concentration of carotenoids $(\mu \mathrm{g} / \mathrm{L})$. 
Table 4 shows the results obtained for the $2^{5-1}$ factorial design. The results showed that the total carotenoid concentration decreased when the yeast extract and peptone concentrations increased in most of the experiments, and that the assays at $\mathrm{pH} 6$ may favour bioproduction. On the other hand, when one of the nitrogen sources was low (yeast extract or peptone) and the $\mathrm{pH}$ was 4 , bioproduction was low in most experiments.

Table 4. $2^{5-1}$ Factorial design (real and coded values) for the optimization of the culture medium for the bioproduction of carotenoids.

\begin{tabular}{ccccccccc}
\hline Assay & $\mathbf{X}_{\mathbf{1}}$ & $\mathbf{X}_{\mathbf{2}}$ & $\mathbf{X}_{\mathbf{3}}$ & $\mathbf{X}_{\mathbf{4}}$ & $\mathbf{X}_{\mathbf{5}}$ & $\mathbf{Y}_{\mathbf{1}}$ & $\mathbf{Y}_{\mathbf{2}}$ & $\mathbf{Y}_{\mathbf{3}}$ \\
\hline 1 & $-1(1)$ & $-1(1)$ & $-1(1)$ & $-1(10)$ & $+1(6)$ & 7.25 & 252.53 & 1831.41 \\
2 & $+1(5)$ & $-1(1)$ & $-1(1)$ & $-1(10)$ & $-1(4)$ & 10.05 & 261.41 & 2627.77 \\
3 & $-1(1)$ & $+1(10)$ & $-1(1)$ & $-1(10)$ & $-1(4)$ & 13.50 & 225.30 & 3042.46 \\
4 & $+1(5)$ & $+1(10)$ & $-1(1)$ & $-1(10)$ & $+1(6)$ & 12.93 & 237.52 & 3070.13 \\
5 & $-1(1)$ & $-1(1)$ & $+1(10)$ & $-1(10)$ & $-1(4)$ & 10.33 & 281.94 & 2912.77 \\
6 & $+1(5)$ & $-1(1)$ & $+1(10)$ & $-1(10)$ & $+1(6)$ & 8.53 & 239.41 & 2041.86 \\
7 & $-1(1)$ & $+1(10)$ & $+1(10)$ & $-1(10)$ & $+1(6)$ & 13.67 & 249.08 & 3404.39 \\
8 & $+1(5)$ & $+1(10)$ & $+1(10)$ & $-1(10)$ & $-1(4)$ & 13.47 & 172.62 & 2325.51 \\
9 & $-1(1)$ & $-1(1)$ & $-1(1)$ & $+1(30)$ & $-1(4)$ & 17.51 & 262.52 & 4891.13 \\
10 & $+1(5)$ & $-1(1)$ & $-1(1)$ & $+1(30)$ & $+1(6)$ & 17.79 & 198.80 & 3535.81 \\
11 & $-1(1)$ & $+1(10)$ & $-1(1)$ & $+1(30)$ & $+1(6)$ & 18.81 & 261.96 & 5099.55 \\
12 & $+1(5)$ & $+1(10)$ & $-1(1)$ & $+1(30)$ & $-1(4)$ & 16.66 & 36.59 & 609.57 \\
13 & $-1(1)$ & $-1(1)$ & $+1(10)$ & $+1(30)$ & $+1(6)$ & 13.60 & 178.57 & 2428.92 \\
14 & $+1(5)$ & $-1(1)$ & $+1(10)$ & $+1(30)$ & $-1(4)$ & 17.87 & 30.51 & 545.10 \\
15 & $-1(1)$ & $+1(10)$ & $+1(10)$ & $+1(30)$ & $-1(4)$ & 16.36 & 42.60 & 696.97 \\
16 & $+1(5)$ & $+1(10)$ & $+1(10)$ & $+1(30)$ & $+1(6)$ & 20.05 & 66.43 & 1332.22 \\
17 & $0(3)$ & $0(5.5)$ & $0(5.5)$ & $0(20)$ & $0(5)$ & 16.14 & 190.52 & 3081.57 \\
18 & $0(3)$ & $0(5.5)$ & $0(5.5)$ & $0(20)$ & $0(5)$ & 16.21 & 186.79 & 3021.27 \\
19 & $0(3)$ & $0(5.5)$ & $0(5.5)$ & $0(20)$ & $0(5)$ & 16.17 & 194.25 & 3141.88 \\
\hline
\end{tabular}

$\mathrm{X}_{1}=$ Yeast extract $(\mathrm{g} / \mathrm{L}) \cdot \mathrm{X}_{2}=$ Malt Extract $(\mathrm{g} / \mathrm{L}) \cdot \mathrm{X}_{3}=$ Peptone $(\mathrm{g} / \mathrm{L}) \cdot \mathrm{X}_{4}=$ Glucose $(\mathrm{g} / \mathrm{L}) \cdot \mathrm{X}_{5}=\mathrm{pH} \cdot \mathrm{Y}_{1}=$ Biomass $(\mathrm{g} / \mathrm{L}) \cdot \mathrm{Y}_{2}=$ Specific concentration of carotenoids $(\mu \mathrm{g} / \mathrm{g})$. $\mathrm{Y}_{3}=$ Volumetric concentration of carotenoids $(\mu \mathrm{g} / \mathrm{L})$.

These independent factors can best be observed individually in Figure 1, where the Pareto graph is presented. In this type of graph, it is possible to verify which are the main factors of greater occurrence in a process, allowing one to concentrate the efforts on them.

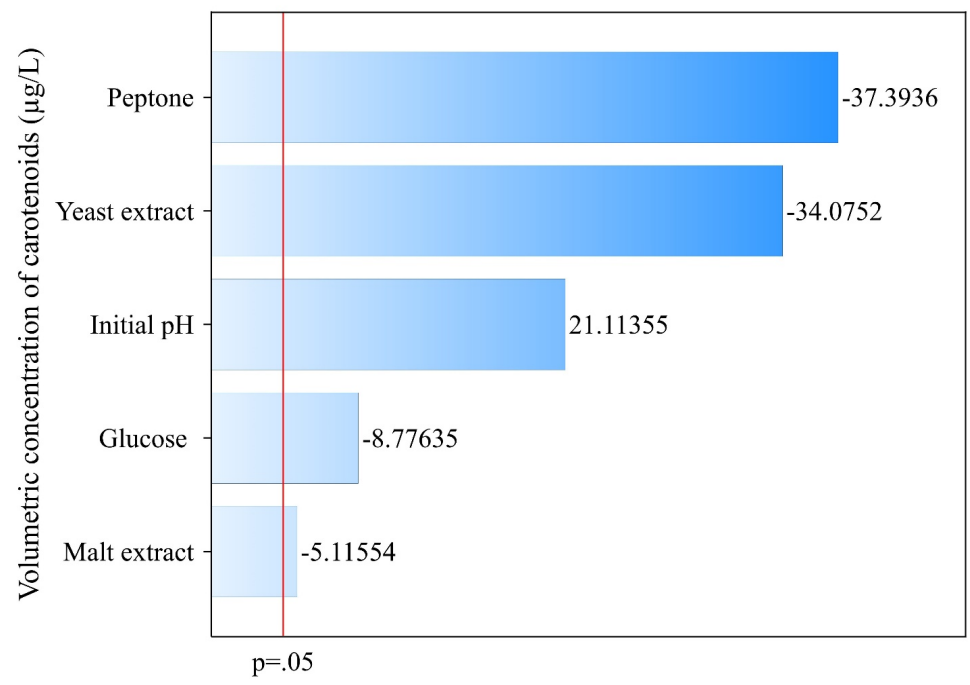

Figure 1. Effect of the variables on the volumetric concentration of carotenoids in the $2^{5-1}$ factorial design at $25^{\circ} \mathrm{C}$ and $130 \mathrm{rpm}$. 
Yeast extract and peptone were shown to be the variables with the greatest influence, with a negative effect on carotenoid production, followed by $\mathrm{pH}$ (positive effect). This inhibitory effect of the yeast extract and peptone can be explained by the excess of nitrogen source or a low $\mathrm{C}: \mathrm{N}$ ratio, which limits the accumulation of carotenoids in oleaginous microorganisms, including the Rhodotorula strains (Taskin et al., 2016). The microorganismproducing carotenoids require minimal amounts of nitrogen, serving as maintenance for their development, allowing the excess carbon in the culture medium to be used for the synthesis of pigments (Spier et al., 2015), a fact observed in this work, for $R$. mucilaginosa, which requires smaller amounts of nitrogen.

For bio-pigment-producing yeasts, organic acids are produced at the start of cultivation, acidifying the medium, and then these acids are assimilated, increasing the $\mathrm{pH}$ value. The use of acidified culture media (initial $\mathrm{pH} 4$ ) causes disarray in the metabolic pathway, impairing the formation of acetic acid, alcohol or the citric acid cycle intermediates during the adaptation phase (Machado \& Burkert, 2015). Aksu \& Eren (2007) studied the $\mathrm{pH}$ range from 3 to 8 , for the production of carotenoids by R. glutinis, and found that $\mathrm{pH} 6.5$ was more favourable for pigment production, because it induced cell growth and high carotenoid production rates.

Therefore, to maximize carotenoid bioproduction, the yeast extract concentrations were modified to lower values, lowering the value from 0.5 to $3.5 \mathrm{~g} / \mathrm{L}$ and increasing peptone from 1 to $5 \mathrm{~g} / \mathrm{L}$, a region close to the central point of Table 4 . As the $\mathrm{pH}$ had a significant positive effect $(p<0.05)$, its levels were shifted to higher values (5.5 to 7.5). Considering that the other variables were significant, such as malt extract $(10 \mathrm{~g} / \mathrm{L})$ and glucose $(30 \mathrm{~g} / \mathrm{L})$ and exerted little influence on carotenoid production, they were fixed at their highest level $(+1)$, for a high $\mathrm{C} / \mathrm{N}$ ratio. In short, the strategy adopted was to reduce the nitrogen sources to better absorb the excess of available carbon sources in the culture medium, as observed in other studies (Spier et al., 2015; Taskin et al., 2016).

In this fractional design $\left(2^{5-1}\right)$, it was found that the significant variables adopting a $5 \%$ alpha were the nitrogen sources (peptone and yeast extract), followed by the initial $\mathrm{pH}$ value. In this type of experimental design, the interactions between the factors cannot be obtained, due to the low number of degrees of freedom in relation to the number of experiments. Fractional designs are used for screening and for the evaluation of important factors that influence the response. In addition, a new design with significant factors was carried out and a new concentration interval was organized to obtain an optimized region.

Table 5 presents the real and coded values for the $2^{3}$ central compound rotational design (CCRD) and the responses in terms of cell concentration, and the specific and volumetric carotenoid concentrations. Table 4 shows that the highest volumetric carotenoid concentrations were obtained in the central point region, while the cell concentration remained practically the same in all the assays.

Table 5. $2^{3}$ Central composite design (real and coded values) for the optimization of the culture medium.

\begin{tabular}{|c|c|c|c|c|c|c|}
\hline Assay & $\mathbf{X}_{1}$ & $\mathbf{X}_{2}$ & $\mathbf{X}_{3}$ & $Y_{1}$ & $Y_{2}$ & $Y_{3}$ \\
\hline 1 & $-1(1.11)$ & $-1(1.81)$ & $-1(5.90)$ & 24.50 & 103.06 & 2715.46 \\
\hline 2 & $+1(2.89)$ & $-1(1.81)$ & $-1(5.90)$ & 25.51 & 129.01 & 3290.67 \\
\hline 3 & $-1(1.11)$ & $+1(4.19)$ & $-1(5.90)$ & 25.68 & 124.01 & 3184.53 \\
\hline 4 & $+1(2.89)$ & $+1(4.19)$ & $-1(5.90)$ & 25.71 & 96.07 & 2469.73 \\
\hline 5 & $-1(1.11)$ & $-1(1.81)$ & $+1(7.10)$ & 23.70 & 123.75 & 2932.41 \\
\hline 6 & $+1(2.89)$ & $-1(1.81)$ & $+1(7.10)$ & 24.28 & 147.44 & 3580.17 \\
\hline 7 & $-1(1.11)$ & +1 (4.19) & $+1(7.10)$ & 23.20 & 119.84 & 2780.57 \\
\hline 8 & $+1(2.89)$ & $+1(4.19)$ & $+1(7.10)$ & 13.47 & 98.63 & 1328.73 \\
\hline 9 & $-1.68(0.5)$ & $0(3)$ & $0(6.5)$ & 25.03 & 148.63 & 3719.66 \\
\hline 10 & $+1.68(3.5)$ & $0(3)$ & $0(6.5)$ & 24.04 & 109.46 & 2971.32 \\
\hline 11 & $0(2)$ & $-1.68(1)$ & $0(6.5)$ & 24.53 & 171.29 & 4201.30 \\
\hline 12 & $0(2)$ & $+1.68(5)$ & $0(6.5)$ & 25.82 & 156.83 & 4050.11 \\
\hline 13 & $0(2)$ & $0(3)$ & $-1.68(5.5)$ & 25.82 & 111.97 & 3532.97 \\
\hline 14 & $0(2)$ & $0(3)$ & $+1.68(7.5)$ & 23.56 & 175.68 & 4139.86 \\
\hline 15 & $0(2)$ & $0(3)$ & $0(6.5)$ & 24.36 & 179.75 & 4379.50 \\
\hline 16 & $0(2)$ & $0(3)$ & $0(6.5)$ & 26.29 & 175.25 & 4269.78 \\
\hline 17 & $0(2)$ & $0(3)$ & $0(6.5)$ & 24.15 & 169.70 & 4134.65 \\
\hline
\end{tabular}

$\mathrm{X}_{1}=$ Yeast extract $(\mathrm{g} / \mathrm{L}) . \mathrm{X}_{2}=$ Peptone $(\mathrm{g} / \mathrm{L}) . \mathrm{X}_{3}=$ Initial $\mathrm{pH}$ value. Glucose $30 \mathrm{~g} / \mathrm{L}$ and malt extract $10 \mathrm{~g} / \mathrm{L}$. $\mathrm{Y}_{1}=$ biomass concentration $(\mathrm{g} / \mathrm{L}) . \mathrm{Y}_{2}=$ Specific concentration of carotenoids $(\mu \mathrm{g} / \mathrm{g}) . \mathrm{Y}_{3}=$ carotenoid production $(\mu \mathrm{g} / \mathrm{L})$. 
In the CCRD (Table 5), the maximum carotenoid production varied from $1328.73 \mu \mathrm{g} / \mathrm{L}$ (assay 8) to $4379.50 \mu \mathrm{g} / \mathrm{L}$ (assay 15) and the biomass concentration from $13.47 \mathrm{~g} / \mathrm{L}$ (assay 8) to $26.29 \mathrm{~g} / \mathrm{L}$ (assay 16) in $144 \mathrm{~h}$. Using the design, the maximum carotenoid concentration increased more than six times and the biomass more than three times, when compared to the maximization of the process conditions (Table 3). The carotenoid values obtained in the present study with $R$. mucilaginosa were higher than those found for other Rhodotorula strains (Lopes et al., 2017; Maldonade et al., 2012).

The statistical analyses were carried out using the Statistica ${ }^{\circledR}$ software version 10.0. The quality of the model fit was expressed by the coefficient of determination $\mathrm{R}^{2}$ and by the statistical significance of the regression. Equations 3 and 4 present the second-order coded model, which describes the volumetric and specific carotenoid concentrations as a function of the independent variables (factors analysed), which were the nitrogen sources (yeast extract and peptone) and the initial $\mathrm{pH}$ within the range studied. The model was validated by the variance analysis (Table 6 ). The factors and their interactions were very significant, less than 0.04 for the $p$-value.

The importance of the p-value is that it demonstrates how significant the terms making up the equation are. The non-significant variables of the model were added to the lack of fit.

Table 6. Variance analysis of the $2^{3}$ central composite design for the yeast $R$. mucilaginosa.

\begin{tabular}{|c|c|c|c|c|c|c|c|c|c|c|c|}
\hline \multirow{13}{*}{ 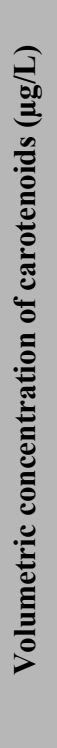 } & 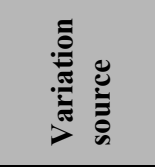 & 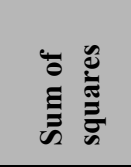 & 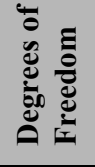 & 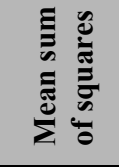 & 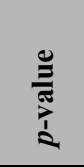 & \multirow{13}{*}{ 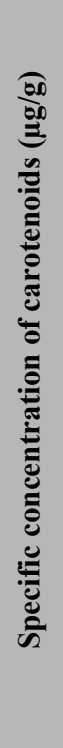 } & 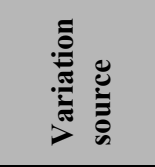 & 氙 & 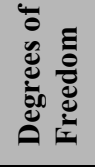 & 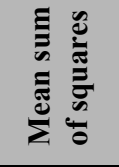 & 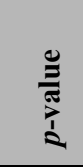 \\
\hline & $\mathrm{x}_{1}$ & 35998 & 1 & 35998 & 0.040 & & $\mathrm{x}_{1}^{2}$ & $\mathbf{5 4 7 3 . 4 9}$ & 1 & 5473.49 & 0.005 \\
\hline & $\mathrm{x}_{1}^{2}$ & 3243249 & 1 & 3243249 & 0.004 & & $\mathrm{x}_{2}$ & 580.55 & 1 & $\mathbf{5 8 0 . 5 5}$ & 0.041 \\
\hline & $\mathrm{x}_{2}$ & 663621 & 1 & 663621 & 0.022 & & $\mathrm{x}_{2}^{2}$ & 1048.84 & 1 & 1048.84 & 0.023 \\
\hline & $x_{2}^{2}$ & 763910 & 1 & 763910 & 0.010 & & $\mathrm{x}_{3}$ & 1531.18 & 1 & 1531.18 & 0.016 \\
\hline & $x_{3}^{2}$ & 1482772 & 1 & 1482772 & 0.010 & & $\mathrm{x}_{3}^{2}$ & 3183.74 & 1 & 3183.74 & 0.008 \\
\hline & $\mathrm{x}_{1} \mathrm{x}_{2}$ & 1436182 & 1 & 1436182 & 0.027 & & $\mathrm{x}_{1} \mathrm{x}_{2}$ & 1219.93 & 1 & 1219.93 & 0.020 \\
\hline & $x_{2} x_{3}$ & 526035 & 1 & 526035 & 0.028 & & Regression & 1012810 & 6 & & \\
\hline & Regression & 6782347 & 7 & & & & Residual & 392064 & 10 & & \\
\hline & Residual & 3705554 & 9 & & & & Lack of fit & 3869.95 & 8 & & \\
\hline & Lack of fit & 3675471 & 7 & & & & Pure error & 50.69 & 2 & & \\
\hline & Pure error & 30083 & 2 & & & & Total & 14048.74 & 16 & & \\
\hline & Total & 10487901 & 16 & & & & & & & & \\
\hline
\end{tabular}

$(p<0.05) ; \mathrm{X}_{1}=$ Yeast extract $(\mathrm{g} / \mathrm{L}) . \mathrm{X}_{2}=$ Peptone $(\mathrm{g} / \mathrm{L}) . \mathrm{X}_{3}=$ Initial $\mathrm{pH}(\mathrm{g} / \mathrm{L})$. Volumetric concentration of carotenoids $\left(\mathrm{R}^{2}: 65.0, \mathrm{R}: 0.80\right)$. Specific concentration of carotenoids $\left(\mathrm{R}^{2}: 0.72, \mathrm{R}: 0.85\right)$.

Another parameter analysed was the coefficients of determination $\left(\mathrm{R}^{2}\right)$ for the volumetric $(65 \%)$ and specific (72\%) responses, which were both higher than $50 \%$, indicating they describe a good part of the experiments. According to Anindyajati et al. (2018), a model having a $\mathrm{R}^{2}$ value greater than $62 \%$ is acceptable. The $\mathrm{R}$ values showed a strong correlation between the variables (yeast extract, peptone and initial $\mathrm{pH}$ value), indicating good significance of the mathematical model in predicting the behaviour of $R$. mucilaginosa. Thus, with a coefficient of determination $\left(\mathrm{R}^{2}\right)$ greater than $50 \%$ and almost all the factors significant, it was possible to construct the contour curve presented in Figure 2a and $b$.

Volumetric concentration of carotenoids $(\mu \mathrm{g} / \mathrm{L})=$

$4324.84-161.30 x_{1}-537.11 x_{1}^{2}-220.54 x_{2}-260.67 x_{2}^{2}-363.17 x_{3}-423.70 x_{1} x_{2}-256.43 x_{2} x_{3}$ 
Specific concentration of carotenoids $(\mu \mathrm{g} / \mathrm{g})=$

$176.64-22.07 x_{1}^{2}-6.52 x_{2}-9.66 x_{2}^{2}+10.59 x_{3}-16.83 x_{3}^{2}-12.35 x_{1} x_{2}$

The 3D contour curves were constructed using the mathematical models obtained, to better explain the interactions between the two factors on the response evaluated. Strong interactions are indicated by darker areas, and thus it was possible to obtain the optimum condition for each response. On the other hand, by overlapping the two figures, it was possible to obtain a region that satisfied both responses, thus reaching the maximum value provided by the two Equations 3 and 4.

According to Figure 2, in order to obtain maximum carotenoid production (volumetric and specific), the peptone concentration should be in the range from 1 to $3.5 \mathrm{~g} / \mathrm{L}$, yeast extract between 1.2 and $2.5 \mathrm{~g} / \mathrm{L}$ and the initial $\mathrm{pH}$ should be adjusted between 6 and 7, maintaining malt extract at $10 \mathrm{~g} / \mathrm{L}$, glucose at $30 \mathrm{~g} / \mathrm{L}$, agitation at $130 \mathrm{rpm}$ and the temperature at $25^{\circ} \mathrm{C}$.

a)

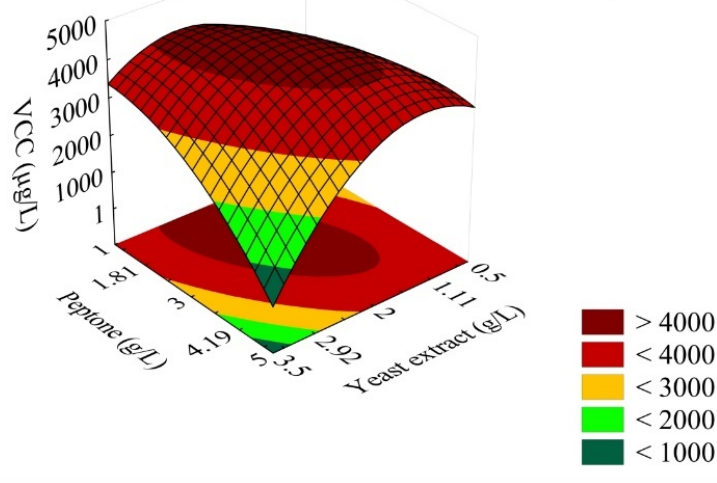

c)

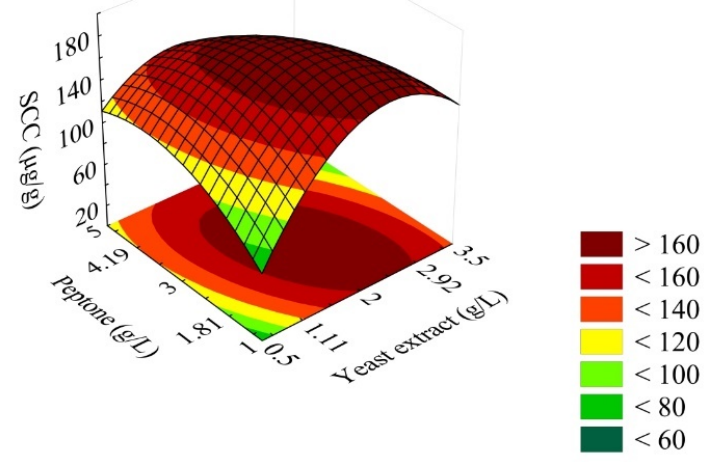

b)

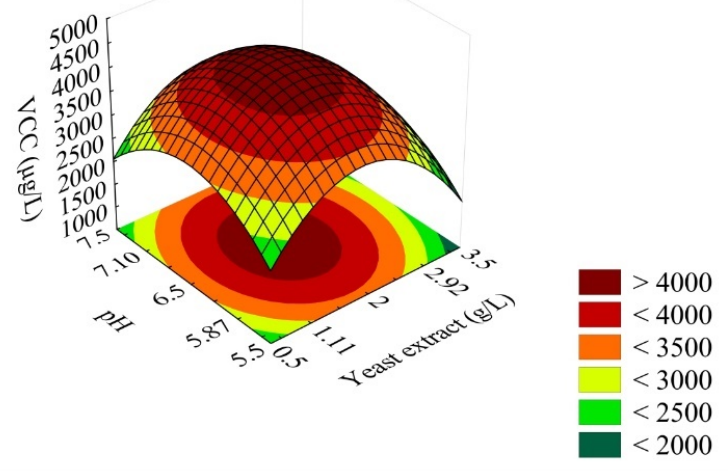

d)

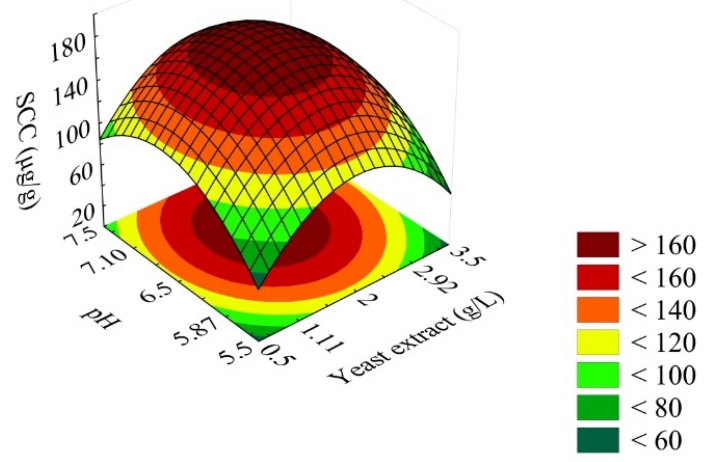

Figure 2. 3D response surface curves for carotenoid production ( $\mathrm{a}, \mathrm{b}, \mathrm{c}$ and $\mathrm{d}$ ) as a function of yeast extract, peptone and initial $\mathrm{pH}$ at $25^{\circ} \mathrm{C}$ and $130 \mathrm{rpm}$ for $144 \mathrm{~h}$. SCC $=$ Specific concentration of carotenoids $(\mu \mathrm{g} / \mathrm{g})$. VCC $=$ Volumetric concentration of carotenoids.

\subsection{Validation of the experiments}

Based on the results of the statistical analyses, triplicate tests were carried out to confirm the predictions of the mathematical models. The optimal condition found for the yeast $R$. mucilaginosa was $3 \mathrm{~g} / \mathrm{L}$ peptone (level 0), $2 \mathrm{~g} / \mathrm{L}$ yeast extract (level 0), $10 \mathrm{~g} / \mathrm{L}$ malt extract, $30 \mathrm{~g} / \mathrm{L}$ glucose, an initial pH of 6.5 (level 0), agitation at $130 \mathrm{rpm}$ and temperature at $25^{\circ} \mathrm{C}$ (a moderate ratio between the carbon and nitrogen sources). 
When the experiment was repeated, a production of $4261.31 \mu \mathrm{g} / \mathrm{L}(252.99 \mu \mathrm{g} / \mathrm{g})$ was obtained. The relative deviations obtained between the experimental results and those predicted by the model during validation were lower than $3.71 \%$ for the volumetric concentration of carotenoids, indicating good reliability of the model (Table 7). On the other hand, the specific concentration was higher than that of the model equation, making it possible to further increase the intracellular concentration of carotene. Therefore, both models were accepted for the prediction of the carotenoid concentrations.

Table 7. Mathematical model validation responses.

\begin{tabular}{ccc}
\hline & VCC $(\boldsymbol{\mu g} / \mathrm{L})$ & SCC $(\boldsymbol{\mu g} / \mathrm{g})$ \\
\hline Response predicted by the model & 4324.84 & 176.63 \\
Experimental response* & 4164.45 & 252.99 \\
Model deviation & -3.71 & 43.23 \\
\hline
\end{tabular}

*Results are means of triplicate assays. VCC $=$ Volumetric concentration of carotenoids. SCC $=$ Specific concentration of carotenoids.

Initially, the carotenoid production using the yeast selected was $635.94 \mu \mathrm{g} / \mathrm{L}$, and reached $4.32 \mathrm{mg} / \mathrm{L}$ by improving the process conditions according to the mathematical model predicted by the design. The same occurred for the initial specific carotenoid production of $122.46 \mu \mathrm{g} / \mathrm{g}$, obtaining a maximum concentration of $252.99 \mu \mathrm{g} / \mathrm{g}$ with the improvements indicated by the design.

Similar behaviour was observed when comparing these results with those found in the current literature. According to Cutzu et al. (2013), of 18 yeasts found in different databases, Rhodotorula glutinis showed prominence in the assimilation of crude glycerol. In the culture medium optimization process, the variables studied were glycerol, yeast extract and peptone, reaching a production of $14.07 \mathrm{mg} / \mathrm{L}$ and increasing the capacity by $280 \%$.

On the other hand, Cabral et al. (2011) used a Plackett-Burman design to improve both the process conditions (agitation and temperature) and the composition of the culture medium for yeast isolated (Sporidiobolus pararoseus), increasing the carotenoid production by up to $45 \%$. It was found that high glucose $(60 \mathrm{~g} / \mathrm{L})$ and malt extract $(15 \mathrm{~g} / \mathrm{L})$ concentrations and low peptone $(15 \mathrm{~g} / \mathrm{L})$ concentrations influenced the bioproduction. In the present work, it was verified that the yeast required large amounts of glucose and moderate amounts of the nitrogen source (yeast extract) for good performance.

In the screening process described by Aksu \& Eren (2007), it was verified that the initial $\mathrm{pH}$ influenced the development of the yeast Rhodotorula glutinis, and that the range from 6 to 6.5 favoured its development, obtaining a final cell concentration of $4.9 \mathrm{~g} / \mathrm{L}$. In the present work, it was verified that the $\mathrm{pH}$ was a significant variable with a positive effect on pigment bioproduction.

Figure 3 shows the average results obtained for the culture kinetics of $\mathrm{pH}$, biomass concentration and the volumetric and specific carotenoid productions during validation of the model in the yeast malt culture medium. 


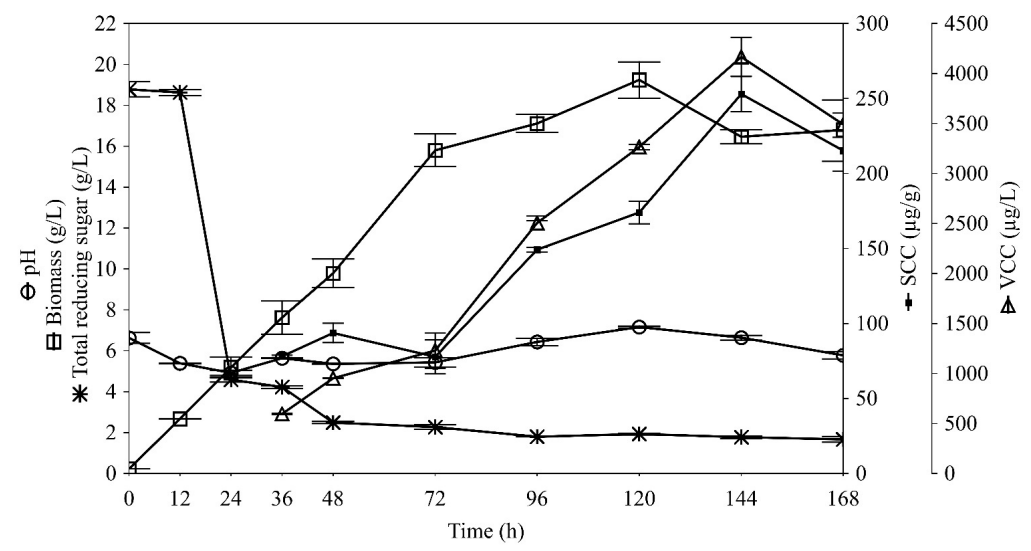

Figure 3. Kinetics of the total carotenoid production by Rhodotorula mucilaginosa according to the empirical models validated using the yeast malt culture medium. $\mathrm{VCC}=$ Volumetric concentration of carotenoids. $\mathrm{SCC}=$ Specific concentration of carotenoids.

Figure 3 shows rapid sugar consumption from $12 \mathrm{~h}$ to $24 \mathrm{~h}$ and rapid cell growth evolution up to $72 \mathrm{~h}$ of the process. In contrast to cell growth, pigment production was low during the first 72 hours and the largest increases in both specific and volumetric carotenoid production were detected after $72 \mathrm{~h}$, at the same time as the values for reducing sugar stabilized.

Similar behaviour was observed for the cell growth of Rhodotorula glutinis in a medium such as beet molasses supplemented with ammonium sulphate (Taskin et al., 2016).

Maximum carotenoid production $(4261.31 \mu \mathrm{g} / \mathrm{L}$ or $252.99 \mu \mathrm{g} / \mathrm{g})$ occurred after $144 \mathrm{~h}$ with a low carbon source concentration $(1.78 \mathrm{~g} / \mathrm{L})$, and from that time onwards, the production decreased. The $\mathrm{pH}$ of the culture showed little variation throughout the process. Similar behaviour was shown for the yeast Sporidiobolus pararoseus in agro-industrial coproducts (crude glycerol and corn steep water) where, after 24 hours of cultivation, the carbon source had been consumed and the carotenogenic phase started (Machado \& Burkert, 2015).

\section{Conclusion}

From the screening carried out in a biodiverse environment (latitude - 20.785218 and longitude 4 9.359897), it was possible to isolate the yeast strain Rhodotorula mucilaginosa URM 7409 on Brazilian territory. The study was carried out in an orbital shaker and the optimum rate of carotenoid production was obtained with a culture medium composed of $30 \mathrm{~g} / \mathrm{L}$ glucose, $10 \mathrm{~g} / \mathrm{L}$ malt extract, $2 \mathrm{~g} / \mathrm{L}$ yeast extract and $3 \mathrm{~g} / \mathrm{L}$ peptone, with a temperature of $25{ }^{\circ} \mathrm{C}$, agitation at $130 \mathrm{rpm}$ and an initial $\mathrm{pH}$ value of 6 . This combination of factors achieved a total carotenoid production of $4261.31 \mu \mathrm{g} / \mathrm{L}(252.99 \mu \mathrm{g} / \mathrm{g})$. The parameters that determined the rate of carotenoid production were the nitrogen sources followed by the initial $\mathrm{pH}$ value. It is to be expected that future studies in aerated reactors and the use of batch feed will surpass the values obtained here. This isolated yeast can be considered as a sustainable source of carotenoids from the perspective of a biorefinery, where diverse valuable components such as lipids, enzymes and antimicrobials are simultaneously obtained.

\section{Acknowledgements}

The authors would like to thank CAPES (Brazilian Agency for the Improvement of Graduate Personnel) and CNPq (National Council of Science and Technological Development) for their financial support. 


\section{References}

Aksu, Z., \& Eren, A. T. (2007). Production of carotenoids by the isolated yeast of Rhodotorula glutinis. Biochemical Engineering Journal, 35(2), 107-113. http://dx.doi.org/10.1016/j.bej.2007.01.004

Amchova, P., Kotolova, H., \& Ruda-Kucerova, J. (2015). Health safety issues of synthetic food colorants. Regulatory Toxicology and Pharmacology, 73(3), 914-922. PMid:26404013. http://dx.doi.org/10.1016/j.yrtph.2015.09.026

Anindyajati, A., Boughton, P., \& Ruys, A. J. (2018). Modelling and optimization of polycaprolactone ultrafine-fibres electrospinning process using response surface methodology. Materials (Basel), 11(3), 441-464. PMid:29562614. http://dx.doi.org/10.3390/ma11030441

Association of Official Analytical Chemists - AOAC. (2012). Official Methods of Analysis of AOAC International (19th ed.). Gaithersburg: AOAC.

Cabral, M. M. S., Cence, K., Zeni, J., Tsai, S. M., Durrer, A., Foltran, L. L., Toniazzo, G., Valduga, E., \& Treichel, H. (2011). Carotenoids production from a newly isolated Sporidiobolus pararoseus strain by submerged fermentation. European Food Research and Technology, 233(1), 159-166. http://dx.doi.org/10.1007/s00217-011-1510-0

Chang, C.-F., Lee, C. F., Lin, K. Y., \& Liu, S. M. (2016). Diversity of yeasts associated with the sea surface microlayer and underlying water along the northern coast of Taiwan. Research in Microbiology, 167(1), 35-45. PMid:26343982. http://dx.doi.org/10.1016/j.resmic.2015.08.005

Cipolatti, E. P., Bulsing, B. A., Sá, C. S., Burkert, C. A. V., Furlong, E. B., \& Burkert, J. F. M. (2015). Carotenoids from Phaffia rhodozyma: Antioxidant activity and stability of extracts. African Journal of Biotechnology, 14(23), 1982-1988. http://dx.doi.org/10.5897/AJB2015.14682

Cutzu, R., Coi, A., Rosso, F., Bardi, L., Ciani, M., Budroni, M., Zara, G., Zara, S., \& Mannazzu, I. (2013). From crude glycerol to carotenoids by using a Rhodotorula glutinis mutant. World Journal of Microbiology \& Biotechnology, 29(6), 1009-1017. PMid:23355137. http://dx.doi.org/10.1007/s11274-013-1264-x

David, B. H. (1976). Carotenoids. In T. W. Goodwin (Ed.). Chemistry and biochemistry of plant pigments (2nd ed.). London: Academic Press.

Dhaliwal, K. M., \& Chandra, N. (2015). Optimization of carotenoids production by Rhodotorula mucilaginosa. International Journal of Pharmaceutical Sciences and Research, 6(3), 1161-1165.

Gómez, L. M., Montañez, J. C., Méndez-Zavala, A., \& Aguilar, C. N. (2014). Biotechnological production of carotenoids by yeasts: An overview. Microbial Cell Factories, 13(1), 12. PMid:24443802. http://dx.doi.org/10.1186/1475-2859-13-12

Libkind, D., \& Van Broock, M. (2006). Biomass and carotenoid pigment production by patagonian native yeasts. World Journal of Microbiology \& Biotechnology, 22(7), 687-692. http://dx.doi.org/10.1007/s11274-005-9091-3

Lopes, N. A., Remedi, R. D., Santos Sá, C., Burkert, C. A. V., \& Medeiros Burkert, J. F. (2017). Different cell disruption methods for obtaining carotenoids by Sporodiobolus pararoseus and Rhodothorula mucilaginosa. Food Science and Biotechnology, 26(3), 759-766. PMid:30263601. http://dx.doi.org/10.1007/s10068-017-0098-y

Machado, W. R. C., \& Burkert, J. F. M. (2015). Optimization of agroindustrial medium for the production of carotenoids by wild yeast Sporidiobolus pararoseus. African Journal of Microbiological Research, 9(4), 209-219. http://dx.doi.org/10.5897/AJMR2014.7096

Maldonade, I. R., Rodriguez-Amaya, D. B., \& Scamparini, A. R. P. (2012). Statistical optimisation of cell growth and carotenoid production by Rhodotorula mucilaginosa. Brazilian Journal of Microbiology, 43(1), 109-115. PMid:24031809. http://dx.doi.org/10.1590/S1517-83822012000100012

Mao, D.-B., Feng, Y.-Q., Bai, Y.-H., \& Xu, C.-P. (2012). Novel biotransformation of betulin to produce betulone by Rhodotorula mucilaginosa. Journal of the Taiwan Institute of Chemical Engineers, 43(6), 825-829. http://dx.doi.org/10.1016/j.jtice.2012.06.006

Michelon, M., Matos de Borba, T., Silva Rafael, R., Burkert, C. A. V., \& Medeiros Burkert, J. F. (2012). Extraction of carotenoids from Phaffia rhodozyma: A comparison between different techniques of cell disruption. Food Science and Biotechnology, 21(1), 1-8, 29. http://dx.doi.org/10.1007/s10068-012-0001-9

Pereira, G. V., Soccol, V. T., Pandey, A., Medeiros, A. B. P., Andrade Lara, J. M. R., Gollo, A. L., \& Soccol, C. R. (2014). Isolation, selection and evaluation of yeasts for use in fermentation of coffee beans by the wet process. International Journal of Food Microbiology, 188, 60-66. PMid:25087206. http://dx.doi.org/10.1016/j.ijfoodmicro.2014.07.008

Saini, R. K., Moon, S. H., \& Keum, Y.-S. (2018). An updated review on use of tomato pomace and crustacean processing waste to recover commercially vital carotenoids. Food Research International, 108, 516-529. PMid:29735087. http://dx.doi.org/10.1016/j.foodres.2018.04.003

Singh, P., Singh, S. M., Tsuji, M., Prasad, G. S., \& Hoshino, T. (2014). Rhodotorula svalbardensis sp. nov., a novel yeast species isolated from cryoconite holes of Ny-Ålesund, Arctic. Cryobiology, 68(1), 122-128. PMid:24463093. http://dx.doi.org/10.1016/j.cryobiol.2014.01.006

Spier, F., Buffon, J. G., \& Burkert, C. A. V. (2015). Bioconversion of raw glycerol generated from the synthesis of biodiesel by different oleaginous yeasts: Lipid content and fatty acid profile of biomass. Indian Journal of Microbiology, 55(4), 415-422. PMid:26543267. http://dx.doi.org/10.1007/s12088-015-0533-9

Taskin, M., Ortucu, S., Aydogan, M. N., \& Arslan, N. P. (2016). Lipid production from sugar beet molasses under non-aseptic culture conditions using the oleaginous yeast Rhodotorula glutinis TR29. Renewable Energy, 99, 198-204. http://dx.doi.org/10.1016/j.renene.2016.06.060 
Evaluation of the process conditions for the production of microbial carotenoids by the recently isolated Rhodotorula mucilaginosa URM 7409

Machado, W. R. C. et al.

Ünlü, A. E., \& Takaç, S. (2011). The effects of pH and temperature on the production of antioxidant enzymes by Rhodotorula glutinis. Current Opinion in Biotechnology, 22, S55-S56. http://dx.doi.org/10.1016/j.copbio.2011.05.151

Valduga, E., Valério, A., Treichel, H., Luccio, M. D., Jacques, R. A., \& Fúrigo Júnior, A. (2007). Pré-tratamentos de melaço de cana-de-açúcar e água de maceração de milho para a bioprodução de carotenóides. Quimica Nova, 30(8), 1860-1866. http://dx.doi.org/10.1590/S0100-40422007000800012

Venil, C. K., Zakaria, Z. A., \& Ahmad, W. A. (2013). Bacterial pigments and their applications. Process Biochemistry, 48(7), 1065-1079. http://dx.doi.org/10.1016/j.procbio.2013.06.006

Wang, D., Ju, X., Zhou, D., \& Wei, G. (2014). Efficient production of pullulan using rice hull hydrolysate by adaptive laboratory evolution of Aureobasidium pullulans. Bioresource Technology, 164, 12-19. PMid:24835913. http://dx.doi.org/10.1016/j.biortech.2014.04.036

Yolmeh, M., \& Khomeiri, M. (2017). Effect of mutagenesis treatment on antimicrobial and antioxidant activities of pigments extracted from Rhodotorula glutinis. Biocatalysis and Agricultural Biotechnology, 10, 285-290.

http://dx.doi.org/10.1016/j.bcab.2017.04.007

Yoo, A. Y., Alnaeeli, M., \& Park, J. K. (2016). Production control and characterization of antibacterial carotenoids from the yeast Rhodotorula mucilaginosa AY-01. Process Biochemistry, 51(4), 463-473. http://dx.doi.org/10.1016/j.procbio.2016.01.008

Received: Oct. 12, 2018; Accepted: Feb. 21, 2019 